\title{
The Autonomy of Conscience: Images of Confession in Mirk's Festial
}

JUDY ANN

FORD

Résumé : Le présent article examine la présentation du sacrement de la confession dans le Festial, recueil populaire anglais de sermons de langue vernaculaire rédigé par John Mirk vers la fin du XIV siècle. En particulier, l'article s'intéresse aux exempla dans les sermons pour le carême, en concluant que les exempla de Mirk dépeignent les pécheurs comme participants autonomes au processus de leur propre salut, capables de communiquer avec la divinité sans intermédiaire clérical. Le Festial était orthodoxe; ses sermons font allusion fréquemment à la nécessité de se confesser à un prêtre. Néanmoins, ses exempla mettent l'accent sur le pouvoir de l'acte laïque, ce qui pourrait expliquer la popularité de ce texte.

For pus I rede of a woman pat had done an horrybull synne, and myght neuer, for schame, schryue hyr perof. And oft, when ho come to schryf, scho was yn purpos forto haue ben schryuen; but euer be fend put such a schame yn hur hert, pat scho had neuer grace to clanse hur perofe. Then, on a nyght, as scho lay yn hur bed, and poght moch on pat synne, Ihesu Crist come to hur and sayde: "My doghtyr, why wol pou not schew me py hert, and schryue pe of pat synne pat pou lyse yn?" "Lord," quod scho, "I may not, for schame." Den sayde Crist: "Schew me py hond"; and toke hur hond, and put hit ynto hys syde, and sayde, and drogh hit all blody out: "Be pou no more aschamed to opyn py hert to me, pen I am to opon my syde to pe."1

This story is from the Festial, a vernacular sermon collection by John Mirk, an Austin canon from Shropshire, probably written in the 1380s as a reference work for priests who were unable or unwilling to compose original pieces for their preaching. ${ }^{2}$ This passage, in which a sinner speaks 
to Christ without an intermediary and is advised by him to unburden herself through "shryf $[t]$," or confession, raises a number of questions about the experience of religion in late medieval England, particularly in regard to the autonomy of individual conscience. What would the men and women standing in the nave of a parish church, listening to this story, have thought about the image of a lay woman conversing with God in private and actually touching his divine body with her mortal hand? What conclusions might they have drawn about a sermon which encouraged auricular confession, yet spoke of a sinner who confronted her God alone? Would they have imagined themselves in her place, speaking directly to Christ?

The question of the degree of lay autonomy in religion during the late Middle Ages is central to the debate over the reformations in England. The conventional interpretation of causality has placed lay initiative in opposition to traditional medieval religion. According to this school of thought, the medieval church consisted of a corrupt clerical and monastic hierarchy, dominated by a well-educated ecclesiastical elite, and an oppressed, largely illiterate laity kept in a state of superstitious ignorance. According to this interpretation, the Protestant reformation occurred when a newly literate, educated and prosperous segment of the laity sought access to the scriptures, and threw off the yoke of clerical and monastic oppression. It is an emotionally satisfying narrative, but one which has been under steady attack for the last two decades by revisionist historians, who have proposed a "top-down" version of the reformation in place of the "bottom-up" version favored by the conventional interpretation. According to the revisionists, the medieval laity - even those who could in no way be characterized as socially or politically elite - had considerable control over their own experience of religion. The Henrician and Elizabethan reformations, by strengthening the church and state, eroded control of religious independence and established a more effective domination by the literate elite - lay and clerical — over the less literate masses. Revisionist historians have argued that ordinary people had more autonomy in religious matters prior to the Elizabethan settlement than they had after it, basing their case on the number of institutions established and controlled by the laity, such as religious guilds and parochial organizations, on lay employment of clergy for chantries and similar institutions, and on the lay organization of many forms of worship, such as those associated with the cult of saints. ${ }^{3}$ The validity of these opposing interpretations is still the subject of much debate among scholars of the English reformation. 
Revisionist history, in this instance, has focused more on behavior than on written expression. ${ }^{4}$ Revisionists, using primarily archival sources such as wills, inventories and church wardens' accounts, have explored what lay people did, especially with their money. In many cases, although certainly not all, these historians have employed quantitative methodologies to recapture the point of view of the average medieval lay men and women, who typically committed few if any of their thoughts to writing. Such scholarship is a necessary corrective to the reliance on the more literary sources upon which the conventional, or "bottom-up," interpretation was based. Works by authors such as Chaucer and Langland, while unquestionably presenting an authentic medieval voice, so patently emerge from the highly literate portion of the laity that it is difficult to see them as representative of the opinions of the majority. Nevertheless, the focus revisionists have placed on archival sources has led to a significant gap in the debate over the reformations in England.

Prescriptive ecclesiastical literature, which instructed the laity not only about how they should behave but also how they should think about the church, their role within the church, and their relationship to the divine, has been largely overlooked by revisionist scholars attempting to determine the late medieval lay experience of religion. Naturally, such sources would have been composed by people who were literate, most frequently by clerical or monastic authors, and may be presumed to reflect their biases to varying degrees. Yet some of this literature, such as Mirk's Festial, was written indirectly for a largely illiterate audience, to whom it would be read. To be effective, it needed to merge the assumptions of its elite authors with the expectations and experience of its non-elite audience. If such texts emphasized images of a passive, obedient laity under the authority of mediating priests, monks and friars, then the autonomy exercised by lay people in their everyday practice of religion may be presumed to have run contrary to the ideological content of the ecclesiology they were taught. If, on the other hand, images of an autonomous, independent laity with direct access to the divine, such as the woman who conversed with Christ in Mirk's story, were typical, then the notion of an oppressive late medieval church posited by the conventional interpretation of the English reformation would be far more difficult to maintain.

The Festial's descriptions of confession may be taken as illustrative of Mirk's representation of the relationship between the church and the laity, because this sacrament was a singularly important point of contact between 
lay people and the official representatives of the church. Mirk's Festial is a lengthy compilation, containing, in the edition of Theodore Erbe, seventyfour sermons for holy days, Sundays and special occasions. Hence, a full consideration of its images of the laity in relationship to the church would be an immense undertaking. A preliminary exploration of these images may be achieved by examining Mirk's presentation of the theory and practice of confession. Within the Festial, discussion of confession is concentrated in the penitential sermons of Lent and Advent, as is not surprising because penitential sermons, particularly those for Lent, were axiomatic in the late Middle Ages for instruction about sin and confession. ${ }^{5}$ This study is confined to the Advent and Lent sermons of the Festial.

Theories of confession were undergoing substantial change during the late Middle Ages, from at least the time of the Fourth Lateran Council (1215). ${ }^{6}$ Scholars have remarked upon the increase in the attention devoted to this sacrament: speculation on the correct use of confession and penance came to dominate the religious literature of the thirteenth and fourteenth centuries. ${ }^{7}$ During the fifteenth century, the period of the Festial's greatest popularity, a theology of confession was being shaped that combined secrecy, interiority and external control. ${ }^{8}$ The penitential works of Jean Gerson, the influential theologian and chancellor of the University of Paris in the early fifteenth century, were influential in this development. ${ }^{9}$ Gerson's writings on confession represent, in the words of Brian Patrick McGuire, "the threshold of modern forms of indoctrination." ${ }^{10}$ Most importantly, the vision of confession he offered positioned the sinner as passive, as the object of examination and transformation by a powerful confessor.

Gerson viewed confession as part of a program of Christian education which was marked by ceaseless observation and examination. He considered that his task as an educator was to extract from children the truth about their lives, so that he could reform them. ${ }^{11}$ Not surprisingly, Gerson also argued that the most effective way to bring adult lay people to Christ was through confession. 12

According to McGuire, Gerson envisioned a confessional practice which allowed the confessor thoroughly to dominate the penitent. He advised confessors to isolate penitents from each other, to put them in a social and emotional vacuum, so that they would have no recourse but to reach out for the sympathy and advice of their confessors. ${ }^{13}$ The confessor, in contrast, must remain emotionally disengaged, while feigning friendship and sympathy for the penitent. In Gerson's words, this pretense was a "pious decep- 
tion," designed to "deceive, cajole and intimidate" the penitent into revealing himself totally. Gerson's approach to confession was much more intrusive than that of his predecessors: he stressed the need for a complete and detailed recounting of the penitent's actions and thoughts. To quote McGuire, Gerson "felt obliged to exercise absolute moral power over his flock ... to spread a sense of guilt and fear ... his strategy ... points to a totalitarian future. The fundamentalistic passion of a Gerson shows us what to expect in the coming Reformation and Counter-Reformation."14

Michel Foucault has explored the development in the early modern period of institutions and systems which claimed ownership over the knowledge and thought processes of the individual, and which professed the authority, in fact, the obligation, to subject the individual to thorough and ceaseless examination. ${ }^{15}$ The advice given by Gerson for a Christian education blends into the characteristics of early modern prisons, schools, factories, hospitals and armies, which, Foucault argues, were designed to correct and transform individuals:

The ideal point of penality today would be an indefinite discipline: an interrogation without end, an investigation that would be extended without limit to a meticulous and ever more analytical observation, a judgment that would at the same time be the constitution of a file that was never closed, the calculated leniency of a penalty that would be interlaced with the ruthless curiosity of an examination. ${ }^{16}$

This trend in late medieval and early modern confessional theory not only mirrored but also seems to have anticipated a development in many other aspects of European culture, namely, the loss of individual autonomy in the face of more effective mechanisms of institutional control.

Scholars of late medieval confession have observed that the loss of individual autonomy was associated with both secrecy and interiority. John Bossy, in his seminal "The Social History of Confession in the Age of the Reformation," argues that the most radical change in the practice of confession was the shift from its being a public event to a private one, a transformation which he believes to have been established in terms of theological theory at the Fourth Lateran Council, but which manifested itself in practice only during the sixteenth century. ${ }^{17}$ The theological change centered on the subject of reconciliation: whereas reconciliation to the community had been the goal of the sacrament prior to the Fourth Lateran Council, reconciliation to God became the goal thereafter. To use Bossy's terms, the traditional notion of confession as "an annual settlement of social accounts" was replaced by "a tendency to psychologize the sacrament: to reinforce the 
desocializing efforts of the earlier scholastics by suggesting that sin was essentially something which occurred in the mind." 18

According to Bossy, the changes in confessional practice took place during the sixteenth century. Prior to that time, confession "was a face-toface encounter between two people who would probably have known each other pretty well. . . . it occurred, normally speaking, once a year, in the not-so-remote presence of a large number of neighbors, and more or less at the time (Maundy Thursday) set aside to the community of public penitents." 19 There is ample evidence that confessions normally took place within a church, in the sight of the congregation, although not within earshot - at least intentionally. The confessional box, introduced during the sixteenth century, physically isolated the confessor and the penitent from everyone else, enclosed them in darkness, and even channeled communication between them through a small grille. ${ }^{20}$ Confession had been withdrawn from the eyes of the community.

Jonathan Hughes's case study of confessional literature in York connects the pan-European transformation of the sacrament with developments specific to England. According to Hughes, both the lay elite and the clergy were instrumental in changing confession. He argues that the increase in interiority, privacy and clerical control was stimulated by an increase in lay literacy and by the appearance of heresies such as Lollardy, particularly Wyclif's attack on the principle of compulsory annual confession to a priest.

Hughes sees the radical changes in confession as part of the growth of privacy among the elite. ${ }^{21}$ In late medieval England, educated lay people began to employ private confessors; the spiritual inclinations of this lay elite led to a greater focus on interiority. ${ }^{22}$ The interior spirituality cultivated by the pious elite did not give them greater autonomy. On the contrary, by the late fourteenth century, pastoral writers had begun to place more emphasis on obedience to authority, and this was communicated both through private confessors and through devotional manuals intended for the educated laity. ${ }^{23}$

At the same time as lay elites sought greater privacy, Hughes argues, the church hierarchy in England was altering confession in order to increase its control over society and counter the development of lay piety and independence in spiritual matters. ${ }^{24}$ Ecclesiastical authorities sought to control society by the shaping of individual consciences. According to Hughes, secrecy was a powerful tool: "The church claimed to exert effective control over the fate of the individual's soul in the next world and used the strictures of eternal punishment to discipline the private thoughts and im- 
pulses of parishioners in this world. It was also able to achieve this because of another unique aspect of the penitential system, its secrecy." $25 \mathrm{He}$ observes that, from the point of view of the church hierarchy, the goal of the late medieval penitential system was "to exert complete control over all aspects of the lives of parishioners." 26

Yet the images of confession presented in the penitential sermons of the Festial suggest a very different understanding of the sacrament. In these sermons, the sinner is an autonomous actor with direct access to the divine, and the process of sin and redemption is an open, public act. In the context of the Festial's theological framework, God and the sinner alone have complete access to the knowledge of an individual's sins, and while representatives of the church may advise the penitent individual, they do not possess a transformative authority. Moreover, confession, guilt and punishment are witnessed; they are open to the eyes of the community. An examination of the models of confession promulgated in the Festial suggests that those who preached its sermons taught the laity to conceptualize the church as a facilitating rather than as a controlling agency, and to think of sins in the context of a human community.

Within Mirk's Festial, the sinner exercises an active agency within a set of knowable and finite laws which seem to bind even God. The agency of the sinner is manifested in the two most common metaphors for confession employed in the Festial: that of sin as a wound and that of the sinner as a defendant in court. Both the healing and the juridical images reflect traditions which can be traced to the early Middle Ages, if not earlier. ${ }^{27}$ These metaphors usually appear in the exempla, the stories embedded in the sermons, which are called 'narrations' (narraciones) by Mirk.

Although Mirk draws on a long tradition in using the metaphor of a wound to speak of sin, the specifics of the metaphor are unusual in the Festial because of the absence of a doctor, an element common in other texts. ${ }^{28}$ Nowhere in the Festial does Mirk use the analogy between a confessor and a doctor. Confession heals the wounds of sin, but, in the language of the Festial, the sinner does not have to submit his body metaphorically to the examination of a doctor/confessor. Instead, the sinner plays a distinctly active role in his own salvation. Representatives of the church, when they appear, provide information and perform the ritual of confession, but they do not examine or treat the sinner as a doctor might a patient.

Mirk dramatically makes the association between bodily wounds and sinfulness in the story of the woman who put her hand into Christ's side. 
The sermons for both the first and the second Sundays in Lent contain this story with a few variations in wording. In this visitation, Christ uses his own wounds as a symbolic equivalent for the sinner's unconfessed guilt, asking her to reveal her sins to him, as he reveals his wounds to her. As there is no human intermediary, there is no metaphorical doctor interposing between the penitent and the divinity.

The absence of a doctor to treat the wound of sin is also conspicuous in a narrative in the sermon for the third Sunday in Lent. This narracio tells the story of a healing miracle revoked, albeit temporarily. Although it is overtly about the need to confess even small sins, it also illustrates the concept of sin as both a literal and spiritual wound, which can be healed through the power of confession. ${ }^{29}$ In the story, a man on crutches goes to an abbey dedicated to Saint Winifred; he prays to the saint and is healed (Mirk, p. 100, 1. 17). But then, the sermon continues:

Also sone as he come ynto hys bed, anon pe sekenes toke hym wors pan hit dyd befor; and soo lay all nyght cryyng pat hit was rewth to here. Then, on pe morrow, mongkes come to hym askyng what he had agylt, pat hys sekenes was comen azeyne. And he sayde: "Nopyng." pen sayde on: "Was pou schryuen sepen pou come?" And he sayde nay.... (p. 100, 11. 21-26)

The man explains that he thinks there is no need for him to confess because he stole no cow or horse, and did no grievous sin. But one of the monks warns him that many venial sins could do considerable damage (p. 100,1. 34). The man is convinced to take action. The sermon reads: "Then pys man toke a prest and schrof hym. And when he was schryuen, anon he had hys hele, and was hole ay after; and heyly ponked God pat he was helut, bopt yn body and yn soule, by confessyon and prayer of pis holy mayden Seynt Wenefryde" (pp. 100, 11.34-36, and 101, 11. 1-2). The language used by Mirk to describe this healing miracle does not suggest passivity. The sinner is clearly an active agent in this story: he journeys to the abbey, accepts the advice of the monks, and then literally "takes" a priest and confesses himself.

Rather remarkably, none of the narratives involving confession in these sermons include a description of the actual procedure. That procedure always takes place outside the narrative, and the confessor rarely appears as a character. Other medieval sermon collections include exempla describing the process of confession, in which the priest is a principal actor, asking questions and drawing out the penitent. ${ }^{30}$ In the Festial, the audience is not permitted to see the confessor act. Instead, stories tell the audience about the choices and actions taken by people who have sinned. 
In place of the process of confession, the process Mirk associates with the wounds of sin is combat. Instead of a passive patient, the sinner in the Festial is an active warrior. The sermon for Advent Sunday explicitly compares the confessed sinner to a valiant knight:

For ryght as a knyght scheweth pe wondys pat he hape yn batayle, yn moche comendyng to hym; ryght so all pe synnys pat a man hath schryuen hym of, and taken hys penans for, schull be per yschewet yn moch honowre to hym, and moche confucyon to pe fende. (p. 2, 11. 16-22)

This analogy conveys the message that sins that have been confessed and repaid by penance are things to be proud of, in the way that a knight might be praised for his battle scars. A confessed sinner carries the scars of sin, not as a grateful patient, but as a successful soldier.

Although the image of a knight in combat is not unusual in penitential literature, other works position the confessor, not the penitent, as the valiant knight. ${ }^{31}$ In Mirk, there are many examples of the penitent as warrior. For example, a story in the sermon for the second Sunday in Lent describes a women bringing her possessed daughter to Christ to be healed. The sermon explains that the possessed daughter is symbolic of a sinner whose conscience is unsuccessfully battling with a fiend; if the sinner confesses to a priest, he will prevail over the fiend (p. 95, 11. 10-11). In the same sermon, Mirk uses a scriptural story about Jacob as the basis for another use of the image of the penitent as warrior. The sermon reads:

He most furst be Iacob ... by Iacob ys vndyrstond a wrasteler. ... When he goth to schryue hym, and hape an horrybull synne, pe fende puttype such a schame yn hys hert, so, pogh hit be yn his mouthe, he may not for schame tell hit out; pen most he wrastyll wyth pe fende, and ouercom hym, and so tell out opynly all pe circumstance perof. (p. $94,11.28-36$ )

The sermon for Palm Sunday uses this image to explain the procession associated with the liturgy of that day. It says that on this Sunday each Christian shall bear palms in procession, showing that he has fought with the fiend and gained victory over him "by clene schryft of mowpe and repentans of hert, and mekely don his penance, and in pis wyse ouercome his enmy" (p. 116, 11. 8-10).

The absence of the process of confession within the narratives of the Festial does not indicate any unorthodox rejection of auricular confession, nor does it suggest that Mirk was advising confession to a lay person. In the text surrounding the narratives, Mirk frequently advises confession to a 
priest. The characterization of the confessor is somewhat surprising, in that it is not that of a powerful authority figure. Instead, Mirk draws attention to the essential similarity between the penitent and the priest. He emphasizes the human, sinful nature of the confessor and argues that this sinfulness is an advantage to the penitent because it makes the confessor more approachable. In the sermon for the first Sunday in Lent, Mirk explains that confession to a mortal priest is a divine concession made by God out of his grace. God selected a representative who is sinful himself, so that people would not be ashamed to confess their sins to him. The sermon reads: "Then take hede wheche an hegh grace God zeuyth you yn demyng, when he ordeynet a synfull man, as pow art, to be py domysman; for all ys yn hegh help to you, to zeve boldnes to you to telle out all pat lythe yn your hert, and nopyng forto hyde..." (p. 90, 11. 1-5).

The active agency of the sinner is clear in Mirk's use of the metaphors of wounds and battle to discuss sin and forgiveness, but it is even more apparent in his metaphor of juridical process. In the Festial's penitential sermons, the sinner often appears as a defendant in a court, making choices within a fixed procedural framework, whose rules must be obeyed by both the sinner and God. The sermon for Advent Sunday describes the judgment of a sinner after death, using the imagery of a courtroom, complete with a judge — that is, a "domesman" — witnesses, and demonic prosecutors:

He schall haue accusars aboue hym, wythyn hym, on aythyr syde hym, and vndyr hym, pat he schall no way scape. Aboue hym schall be Crist his domes-man so wrope, pat no tong con tell, for he dyt no mercy; wythyn hym his on concyens accusyng hym of pe lest poght pat euer he dyd amys; hys angyll on pat on syde tellyng hym redely wher and how oft he hape don amys; on pat oper syde fendes chalenchyng hym horres as by ryght; vndyr hym helle zeonyng, and galpyng, and spyttyng fyre and stench redy forto swolon hym ynto pe payne pat neuer schall haue ende. (p. 4, 11. 23-32)

The sermon for the first Sunday in Lent explicitly links hell with prison in these words about the unrepentant sinner: God "wyll make bynde hym hond and fote, and cast hym ynto prison, pat ys, ynto pe paynes of helle" (p. 91, 11. 5-6).

Earthly confession, according to these sermons, is a way of avoiding the most dreadful consequences of this post-mortem trial. According to the theology of the Festial, God is bound by juridical procedure and must damn all who die in a state of sin. Since it is assumed that everyone will sin, in the absence of some alternative procedure, God would be compelled to damn everyone. He therefore created confession as a procedural loophole, through 
which the sinner may choose to provide compensation to God while still alive and thus relieve God of the obligation of sentencing the sinner to the prison of hell. The sermon for the first Sunday in Lent explains:

Thus, for he sees pat no man may scape his dome vndampned, perfor he, of hys hegh grace, zeuyth hys power to a curatour, to deme all pat comen to hym, hauyng ferme and stabull all pat comyth to hym; as pus per schall no good dede be vnquyte, nor no euell vnponysched. Therfor yf a curatour zeue pe more penaunce pen pe nedyth, pat ys more, hit schall be quyte, and stonde pe in gret joye of encrese byfor God; $3 y f$ he zeue pe euen, pou art quyte; but yf he zeue pe to lytyll, pen schall hyt be fulfylled yn purgatory. Soo pat a man schall neuer be dampned for no synne pat he ys mekly schryuen of, and takyth hys dome mekely of hys schryftfadyr; for all pyng pat ys not clansed here by schryft and penance, schall be clansed yn purgatory. (p. 89, 11. 23-35)

God thus binds himself not to condemn anyone for a sin which has already come up before his representative, even if his representative imposed a penalty inappropriately heavy or light. And the penalty will "quyte" the sinner before God - a term which implies the end of indebtedness in a legal or financial sense. The legal metaphor is continued in the same sermon in the promise that God will abide by the rule of double jeopardy: " ... wherfor God woll neuer deme pe twy for on pyng" (p. 90, 1. 1).

The last section of this sermon stresses God's "grace yn amendys makyng" (p. 90, 1.31), that is, God's willingness to allow the sinner to choose or to reject forgiveness. In these sermons, sinners exercise free will, whether their choices lead them to salvation or damnation, without the controlling influence of a human intermediary or the direct intervention of a deity. God does not automatically impose a sentence; he abides by the choice the individual makes. The sinner retains his freedom of action, at least until death. God, who presumably knows about sins committed, is shown trying to persuade the sinner to confess. As a character in Mirk's sermons, God offers a reciprocal exchange of knowledge as part of the process of persuasion and does not resort to force, even in the face of obstinate refusal to take advantage of the benefits of earthly confession.

An example of a voluntary, reciprocal exchange of knowledge may be found in the narratives in which the wounded Christ appears to a woman who is too embarrassed to confess a grievous sin. In both versions of the story, he exchanges knowledge of his "heart," allowing her to violate the integrity of his body, in return for her revelation of sins which she would rather not relate. A narrative in the sermon for the first Sunday in Lent provides a variation of this story, in which the reciprocal exchange goes 
wrong. In this version, a chapman who has lived sinfully and never confessed is about to die, when he is visited by the wounded Christ. Christ twice encourages the man to confess his sins and is twice refused. Finally, in what seems to be a fit of temper, Christ reaches his hand into his own side, draws it out bloody, and flings his blood into the man's face, saying, "Pou fendys-chyld, pys schall be redy token bytwyx me and pe yn pe day of dome, pat I wold haue don pe mercy, and pou woldyst not" (p. 92, 11. 12-14). The man cries out that he is now damned, and dies. Certainly the narrative would serve to encourage a willingness to confess in this life because of the consequences of refusal; nevertheless, the sinner in the story retains free choice and is allowed to select his own fate without any human agency intervening between him and divine judgment.

In the sermon for the first Sunday of Lent, there is another narrative which illustrates the ability of the sinner to chose his own path, even to damnation, without the interference of a coercive, examining authority. In this narrative, an impoverished knight robs and kills a merchant to obtain the money to marry a wealthy lady. The knight, on the advice of the lady, goes back to visit the murdered body at midnight, where the following scene takes place:

And at mydnyght per come a lyght from Heuen downe to pe graue; and pen pe graue opened, and pe cors sate vp, and helde vp his hondys to God, and sayde: "Lorde pat art ryghtwys juge, bou wreke me apon pis man pat hape pus falsly slayne me for my trew catayle." And perwyth come a voyce from Heuen and sayde: "Thys day prytty wyntyr, pou shalt haue vengeans": and pen pe cors ponkyd God, and lay downe yn hys graue azeyne. (p. 88, 11. 21-28)

The knight and the lady choose to ignore the warning, explicitly deciding not to confess, and they live well for thirty years. No priest or confessor is introduced in the story at all; the suggestion is that three decades pass without any consultation with a member of the clergy on the matter. In the end, the knight and the lady are plunged into hell, but, like the chapman in the previous story, they are autonomous agents, who clearly do not answer to anyone but God for their conduct.

Just as the sermons in the Festial present images of lay autonomy rather than of clerical control, they also reflect the traditional expectation that confession was more a public matter than a private one. The public, open nature of guilt and confession is conveyed in Mirk's penitential sermons in two ways: by the visible manifestation of guilt on the body of the sinner and by the presence of witnesses when damnation occurs. 
The visible nature of sin as manifested by physical marks on the body is a theme running through many of Mirk's penitential narratives. A good example is the story of the women who was invited by Christ to put her hand into his side to feel his heart. Christ's blood remained on her hand as an open sign of her sin until she confessed. The sermon reads: "Then was pys woman agrysed of pe blod, and wold haue weschyn hit away; but scho myght not, be no way, tyll scho had schryuen hur of pat synne. Then, when scho was schryuen, anon pe hond was clene as pat opyr" (p. 90, 11. 26-30). The story of the unrepentant chapman illustrates, not only the presence of Christ's blood, but also a physical transformation of the body. The chapman was found dead after his rejection of Christ's offer of forgiveness, "pe red blod yn hys face, and pe body blacke as pych" (p. 92, 1. 20). The demonic cause of the blackening of the unrepentant body is explained in the sermon for the third Sunday in Lent in a story of an abbess given to ribald talk:

I rede of an abbas pat was a clene woman of hyr body as for dede of lechery; but scho had gret lust to talke perof. So when scho was ded, scho was buryet yn pe chyrch. And so, pe ny3t aftyr, fendes token vp pe body, and beten hyt wyth brennyng scorgys from pe nauell vpward, pat hyt was as blak as pych; but from pe nauell donward, pay myght do nozt perto, for pat part schon as pe sonne. (pp. 96, 11. 33-34, and 97, 11. 1-5)

This same narrative demonstrates that the function of these visible, bodily signs was to bear public witness to sin, to make it open and known to others. The dead abbess, as she was being beaten by devils, cried so loudly that she was heard by two living nuns of her convent. The two nuns went to where the body lay to see what was wrong. The abbess, though dead, was able to explain both her sins and her condition to them:

Then sayde scho to hur sustren: " $3 \mathrm{e}$ knowen well ynogh pat I was clene mayden as for dede of flessche; wherfor pat party of my body pat was clene, pat schynyth as ze se now. But, for I had lust forto speke of fulth of pe flessch and opyr rybawdy, perfor pat party of my body pat ys gulty, hit hape hys penaunce as ze seen. Wherfor I pray you pat ze pray for me; for by your prayers I may be holpen, and bupe war by me yn tyme comyng." (p. 97, 11. 8-15)

The abbess's guilt is expressed externally, bodily, rather than being interiorized, and her body is then used as a public teaching device. There is no reflection of the private, "psychologized," directed confession of sin within these narratives.

The presence of witnesses is a common element in the narratives of these sermons. Not infrequently, explaining the presence of witnesses and the conditions of witnessing becomes a significant part of the narrative. For 
example, in the story of the impoverished knight who robbed and murdered a merchant in order to marry a wealthy lady, Mirk could have simply told the story of the couple's sin, their avoidance of confession and their punishment, which was to be sent into hell with their castle and all their friends. Instead, Mirk introduces a witness, who miraculously survives the massacre. As the date foretold for God's vengeance approached - thirty years after the sins were committed - the knight and the lady decided to secure themselves inside their castle, invite all their friends and have a feast. The lady assures her husband that with such a plan, they "schall scape wele ynogh" (p. 89, 1. 3). At this point in the story, which is thirty-eight lines into a forty-six line text, only the principal characters have appeared: the knight, the lady, the merchant and God. Here Mirk introduces a harper and the ghost of a kitchen worker (the "brothell"), who serve, respectively, as the witness and the supernatural mechanism for allowing the witness to survive. The harper provided music during the feast, until

... per come out of pe kychon a bropell bowdet wyth gres, and rubbyd hys stryngys wyth hys bawdy hondys. Then was pys harper wondyr wroth, and wyth hys harpe wold haue smyton thys brothell; but for he flagh fast away, pe harper suet hym out of pe castell; and when he come out, pis brothell vaneschyd away. Then pys harper turned azeyne, and sygh pys castell synke ynto pe erpe, all on fyre. (p. 89, 11. 8-14)

The moral intended by Mirk - namely, that one should go to confession in a timely manner - is specified after the narrative. The audience is advised not to abuse God's patience, "but bythynkyth you wele of your mysdedys, and comyth by tyme and clansyth you" (p. 89, 11. 17-18). The witness in this story serves to create a public memory of the consequence of failure to repent.

A similar pattern appears in the narrative concerning the chapman who would not go to confession, and who, on his death bed, refused Christ's offer of mercy. In this story, Mirk not only provides witnesses, but he also takes pains to explain how the witnesses could see the events, since the divine visitation took place at night: "Pen had pys man a lampe brennyng on nyghtys byfor hys bed, and yn a bed bysyde hym lay oper two men, to wake hym. Then, about mydnyght, pay saw Ihesu Cryst bodyly wyth blody wondys stondyng before pe seke manys bed"' (p. 92, 11. 1-4). The conversation between the chapman and Christ is related from the point of view of the witnesses. After the chapman dies, the narrative takes up the actions of the braver of the two witnesses: 
Then pys oper man was so aferd of pys syght and of bope hor speche, pat hit was long or he dyd ryse. Then, at pe last, he ros vp, and lyght a candull at pe lampe, and come to hys felow, and fond hym dede, and pe red blod yn hys face, and pe body blacke as pych. pen, for ferd, pys man cryed for helpe; and when men comen, he told hom pe case, and how Cryst dyd to hym, and how he vnswared azeyne. (p. 92, 11. 16-23)

The moral of this narrative is the same as in the case of the knight and the lady: the audience is advised not to take God's grace in vain, "but schryue you clene of your synnes" (p. 92, 1.25). The witnesses in this story are present to make public the communication between the human and the divine. Far from being "psychologicized," to use Bossy's term, the interplay between the sinner and his God, the struggle - unsuccessful in this case - to overcome pride so far as to confess wrongdoing, is rendered a visible drama. No confessor is in attendance to direct or control the exchange; the two principals interact unimpeded by intermediaries. The only purpose of the others present in the room is to tell the story to the community.

In the active agency ascribed to the sinner by Mirk, in the absence of a confessor who exerts control through rigorous examination, and in the public nature of guilt and repentance, the Festial may be said to deviate from the confessional currents of its age, as scholars have found them expressed in canon law and confessors' manuals. The divergence probably reflects a difference in the intended audience. Canon law and confessors' manuals were intended for a clerical and monastic audience; some of the confessors' manuals enjoined that their texts be kept from the laity for fear that the descriptions of sin contained in them might inspire new transgressions. ${ }^{32}$ The new program for confession advanced official public authority; it is hardly surprising that it is found in religious sources, which were directed to an elite audience. Literary works, such as Chaucer's Canterbury Tales, seem also to reflect the new, more oppressive theories of confession. According to Mary Flowers Braswell, the quality of "engin," that is, the ability to control and manipulate situations in a literary work, became less associated with the confessed sinner in literature as early as the thirteenth century, contemporaneous with the Fourth Lateran Council of $1215 .{ }^{33}$ Like confessors' manuals and canon law, literary works were probably not accessible to the average lay person, although the lay elite certainly constituted a target audience. It is impossible to reconstruct how much of the content of either literary or ecclesiastical texts reached the mass of illiterate laity, or even the functionally literate laity, who did not belong to the leisured classes and did not have a liberal education. ${ }^{34}$ Some content may have been 
communicated through conversations with, or lectures by, clergy or lay people who were better educated. Some works may have been read by those who could as entertainment for those who could not. Nevertheless, neither canon law, confessors' manuals nor high-culture literary works seem to be the best sources for understanding what the average lay person in late medieval England was taught regarding confession.

The ordinary lay person was instructed about religion in other ways, principally through sermons. For such people, who acquired much of their religious education haphazardly, through church art, plays and the liturgy, sermons typically constituted their only organized religious instruction, and it was through this medium that they acquired a great deal of their knowledge about Christian theology, spirituality and morality. Late medieval sermon collections thus constitute a valuable and under-utilized source of information about the ideology of confession, as it was presented to the uneducated laity. ${ }^{35}$ Sermon collections written for a non-elite audience, even one as popular as the Festial, were denigrated by early modern critics and have been ignored by modern scholars. ${ }^{36}$ The early modern bias is described in detail by $\mathrm{H}$. Leith Spencer. ${ }^{37}$ Spencer notes that sermons intended for a rural audience were considered inferior by urban audiences in early modern England, adding that "a sophisticated urban audience is unlikely to relish being addressed in a manner deemed at best suitable for yokels." 38 The class differences and religious polemics of reformation England render this attitude comprehensible, but the dismissive attitude of modern scholars is more difficult to understand.

Peter Biller's introduction to a volume devoted to medieval confession is typical in its dismissive treatment of sermon literature. His chapter begins by quoting and commenting on a few excerpts from sermons, then explains that his

introduction ... takes these stories ... as a few rare colorful snapshots. . . They constitute a prelude to ... the next section, which concentrates on the principal surviving textual traces of medieval confession: church legislation, and the many works, extant in enormous numbers of manuscripts, which told a priest how to hear confession and impose penance. ${ }^{39}$

The most popular sermon collections, such as Mirk's Festial, have not been recognized by most scholars for the potential insight they offer into the religious beliefs of the masses. The format of the Festial, particularly its use of exempla to convey meaning, has led modern scholars to dismiss it as both old-fashioned and inferior to much other late medieval English sermon 
literature ${ }^{40}$ For example, G. R. Owst's classic survey of medieval sermons refers to Mirk's work as "simple and superstitious." 41 Critics have pointed to its over-reliance on hagiography, the relative dearth of scriptural commentary, and a seeming neglect of the new devotional theories which were circulating at that time. In addition, the Festial has been considered less worthy of study than other late medieval sermon literature because Mirk wrote for a relatively ignorant audience - for the rural, the uneducated, the illiterate. Stroup's evaluation of the Festial is fairly typical:

The characteristics of medieval preaching as seen in John Mirk's sermons begin to come clear and suggest reasons for their popularity with the listener of that day. For one thing, scripture is used in a fanciful and embellished pattern, usually by symbolic or allegorical means, so that it takes on the nature of a story and tends to parallel in style and emphasis the highly popular saints' tales and legends of the time. ${ }^{42}$

Sermon scholars often seem to privilege the elements of religion associated with the Protestant reformation. Thus there is a tendency to evaluate the quality of medieval sermons according to the ratio of "reformed" versus "traditional" elements, in which "traditional" is typified by a story-telling approach and a reliance on saints' legends, while "reformed" denotes a more didactic, scripturally-based style. According to this bias, the more traditional a sermon, the less worthy it is of serious scholarly consideration.

English sermon collections composed with a popular audience in mind almost invariably favor the traditional sermon style, which scholars have commented on almost exclusively in reference to its entertaining nature, rather than its theological content. Stroup, for example, assumes that the style of constructing sermons followed by Mirk, and others, was simply a crude mechanism to please an easily bored audience. He writes:

One means of holding the attention of the congregation was through the introduction of stories, saints' tales, and legends, called "exempla." This pattern became quite typical of medieval sermons and was the source of much abuse by the preacher who increasingly indulged in flights of fancy in order to entertain rather than illustrate. ${ }^{43}$

This opinion is even more strongly expressed by Owst:

With Myrc (sic) the text of canonical scriptures would seem almost out of favour. He revels in the most fanciful and impossible anecdotes about sacred characters; he is fascinated irresistibly by the lurid and painful; he seems to offer his listeners little short of a new superstition and wizardry blessed by the Church, in place of the old forbidden paganisms to which they still cling so lovingly. ${ }^{44}$ 
Such dismissive evaluations have been offered even by those historians who seem aware that the reformed style could be linked to inquisitorial control. Consider the appraisal provided by Jonathan Hughes of Robert Manning's Handlyng Synne, a fourteenth-century penitential tract which achieved local popularity in northern England, and which employs the same exemplumbased format as the Festial:

\footnotetext{
... his main purpose seems to have been to entertain: he attempted to appeal to "lewd men" who listened to tales and rhymes by reducing the emphasis on penitential teaching and expanding the exemplas ... to provide entertaining and instructive tales on the deadly sins. ... Manning therefore reveals the importance of penitential anecdotes as a source of entertainment and gossip for ordinary parishioners, but he reflects this interest too passively to be a significant pastoral figure. He does not show any inquisitorial rigor or pedagogic purpose and seems to have acted without any ecclesiastical supervision or encouragement. ${ }^{45}$
}

What needs to be considered is that popular sermon collections such as Handlyng Synne and the Festial may be more reflective of popular culture than penitential tracts written for more theologically sophisticated, urban audiences, and may thus possess even greater value for historians attempting to understand how religion was experienced by the majority of people in late medieval England, whose population was overwhelmingly rural and uneducated.

An analysis of confession in the Festial suggests that there may have been compelling reasons why its theology was more attractive to those who were excluded from the elites, groups increasingly defined by their literacy. The use of exempla instead of scriptural commentary as the essential content of sermons can be interpreted, not as an unimaginative retention of an "old-fashioned" format, but as a deliberate attempt to communicate with an audience who would not have had the ability or opportunity to study the Bible. The exempla may have conveyed an image of individual Christians less subject to coercive, examining authority mediating between them and the divine. In other words, the audience, instead of being merely credulous and seeking to be entertained, may have found within the narratives a type of agency that they found appealing in the face of the encroaching powers of a reformed church and a more efficacious state.

Analysis of the presentation of confession in Mirk's Festial suggests possibilities for reinterpreting the ideology of confession in late medieval and early modern Europe and provides some evidence for a high degree of lay autonomy in pre-reformation England. Such a case study cannot furnish 
conclusive answers with respect to either of these large and complex issues. Yet it does underline the utility of popular sermon collections in examining them, indicating that further study along these lines should prove fruitful. Moreover, it reinforces the notion that historical developments such as the reformation were not linear, and that recovering either the persistence of older ideas or the resistance to newer ones among any segment of the population adds to a more accurate reconstruction of the past. ${ }^{46}$

Texas A\&M University - Commerce

\section{Notes}

1. Johannes Mirkus (John Mirk), Mirk's Festial: A Collection of Homilies, ed. Theodor Erbe (London: Kegan Paul, Trench, Trubner for the Early English Text Society, 1905), p. 90, lines 15-26. References to this edition, by page and line numbers, will henceforth appear within parentheses in the text.

2. This paper is based upon an edition of a Group A text of the Festial, which was by far the most common form of compilation. For an explanation of the $\mathrm{A}$ and $\mathrm{B}$ groups of extant manuscripts of the text, see Susan Powell, "John Mirk's Festial and the Pastoral Programme," Leeds Studies in English, n.s. 22 (1991): 85-102. For a discussion of the composition and purpose of the Festial, see Powell, pp. 85-86, and Herbert W. Stroup,"John Mirk: Tutor to England's Medieval Preachers," The Bulletin 47.3 (Summer 1967): 26.

3. The scholarly work on this topic is voluminous. Some of the works most illustrative of the two broad schools of interpretation are: Claire Cross, The Church and People 1450-1660: The Triumph of the Laity in the English Church (Cambridge: Cambridge University Press, 1976); Arthur G. Dickens, The English Reformation, 2nd ed. (London: Batsford Press, 1989); Eamon Duffy, The Stripping of the Altars: Traditional Religion in England c.1400-c.1580 (New Haven: Yale University Press, 1992); Peter Heath, The English Parish Clergy on the Eve of the Reformation (London: Routledge and Kegan Paul; Toronto: University of Toronto Press, 1969); John J. Scarisbrick, The Reformation and the English People (Oxford: Basil Blackwell, 1984); and Robert Whiting, The Blind Devotion of the People: Popular Religion and the English Reformation, Cambridge Studies in Early Modern British History (Cambridge: Cambridge University Press, 1989). A useful summary to the beginning of this decade may be found in the bibliographic review by Peter Heath, "Between Reform and Reformation: the English Church in the Fourteenth and Fifteenth Centuries," Journal of Ecclesiastical History 41 (1990): 647-78.

4. A clear and detailed explanation of this focus may be found in Christopher Haigh, English Reformations: Religion, Politics and Society under the Tudors (Oxford: Clarendon Press, 1993).

5. Confession, although as one of the sacraments clearly intended to be a means of attaining grace, was viewed by the church as a vital occasion of instruction and correction, especially during the late Middle Ages: William Pantin, The English Church in the Fourteenth Century (Cambridge: Cambridge University Press, 1955), 192. 
6. There is some scholarly disagreement concerning the chronology of this transformation, with some scholars favoring as the most significant point of divergence the legislation of the Fourth Lateran Council (1215), specifically the decree Omnis utriusque which made annual confession to one's parish priest mandatory, and other scholars arguing that more meaningful changes in practice occurred during the reformations of the sixteenth century. A brief discussion of the controversy over chronology may be found in Peter Biller, "Confession in the Middle Ages: Introduction," in Handling Sin: Confession in the Middle Ages, ed. Peter Biller and A. J. Minnis, York Studies in Medieval Theology, 2 (Woodbridge, Suffolk: York Medieval Press in association with The Boydell Press, 1998), p. 30. Recently, there have been efforts to suggest that real change developed gradually between these two points of discontinuity, becoming noticeable in the late fourteenth and fifteenth centuries. For example, see Jonathan Hughes, "The Administration of Confession in the Diocese of York in the Fourteenth Century," in Studies in Clergy and Ministry in Medieval England, ed. David M. Smith, Purvis Seminar Studies, Borthwick Studies in History, 1 (York: University of York, 1991).

7. Pantin, p. 192.

8. For the Festial's popularity, see Powell, pp. 87 and 93.

9. Although one might question the impact a Parisian theologian such as Gerson might have on developments in England, his theology is generally recognized as having a profound influence on confessional theory throughout Europe. John Bossy, for example, characterizes Gerson as "a real pathfinder" (Christianity in the West, 1400-1700 [Oxford: Oxford University Press, 1985], pp. 48-49). Biller goes so far as to use Gerson as the main point of demarcation, using the phrase "the pre-Gerson Church" (p. 16). Thomas N. Tentler remarked of Gerson that "[h]is is the greatest voice in the cure of souls" (Sin and Confession on the Eve of the Reformation [Princeton, NJ: Princeton University Press, 1977], p. 46). An English example of Gerson's influence may be found in William Lynwood's Provinciale seu constitutiones Angliae (c. 1422-1430), probably the most influential work on confession in England during the fifteenth century, which emphasized the inquisitorial role of the confessor rather than his teaching function (Hughes, p. 104).

10. Brian Patrick McGuire, "Education, Confession and Pious Fraud: Jean Gerson and a Late Medieval Change," American Benedictine Review 47.3 (1996): 311.

11. Ibid., p. 320.

12. Ibid.

13. Ibid., p. 334.

14. Ibid., p. 338.

15. See, for example, Michel Foucault, Discipline and Punish: The Birth of the Prison, trans. Alan Sheridan (New York: Pantheon Books, 1977).

16. Foucault, p. 227.

17. John Bossy, "The Social History of Confession in the Age of the Reformation," Transactions of the Royal Historical Society 25 (1975): 26.

18. Ibid., p. 22-27. 
19. Ibid., p. 24.

20. Ibid., p. 29.

21. Hughes, pp. 109-10.

22. Ibid., p. 101.

23. Ibid., p. 124.

24. Ibid., p. 101.

25. Ibid., p. 117.

26. Ibid., p. 111.

27. The theory of confession during the Carolingian period, particularly as expressed by Alcuin of York, is analyzed by Michael S. Driscoll in "Penance in Transition: Popular Piety and Practice," in Medieval Liturgy: A Book of Essays, ed. Lizette Larson Miller, Garland Medieval Casebooks, vol. 18 (New York: Garland Publishing, 1997). According to Driscoll, the penitential practices of Celtic monks in the sixth and seventh centuries were combined with Germanic legal traditions of the same period to become a fully-formed theory of sacramental confession during the Carolingian renaissance, articulated by such influential theologians as Alcuin of York (ca. 735-804). The Celtic monks confessed their sins to one another, and imposed the penances listed in the penitential books as appropriate for the specific sin committed. They looked upon each penance as a medicine which corresponded to a specific illness. The Germanic legal traditions of the Early Middle Ages which were combined with Celtic confessional practices revolved around wehrgeld, a reciprocal system wherein one party suffered the punishment a paying a fine in what was supposed to be exact proportion to the wrong that party had inflicted on another party. In other words, penitential compensation had to be made to God in rough equivalency to the injury or insult caused by the sin. According to Biller, the analogy of a confessor to a physician of the body was ancient and had been applied to Christ by the early church fathers. It was also used in the decree Omnis utriusque of the Fourth Lateran Council (Biller, pp. 7-8).

28. Examples can be found both in very early penitential literature and in works contemporary with Mirk's Festial. For example, in the eighth century, Alcuin of York wrote: "By contrast, it is all the more necessary to attach yourself to the remedy of confession. Oh sinner, otherwise you will rot in the gangrene of your wounds, if you blush to uncover to the doctor the multiple aches of your ulcers" (cited in Driscoll, p. 145 [Driscoll's translation]). During the fourteenth century, William of Pagula, Richard Rolle and John Burgo, all authors of penitential literature popular in England, compared the confessor to a doctor removing poison from a wound (Hughes, p. 118).

29. The advisability of frequent confession is common in Mirk. Consider this directive in the sermon for Advent Sunday: "And for dred of deth he mot make hym redy to his God, when he woll send aftyr hym, pat ys: schryuen of his synnys, and allway kepe his concyens clene not forto abyde from lenton to lenton, but as sone as he felepe pat he hath synnet, anoon goo schryue hym ..." (p. 2, 11. 10-15).

30. For example, Caesar's Dialogue of Miracles (c. 1223) (Biller, pp. 4-5). 
31. See Alexander Murray, "Counseling in Medieval Confession," in Biller and Minnis, eds., p. 75.

32. During the late Middle Ages there was a body of literature being created for the elite, educated layman who employed a personal confessor, which might be called guides for the examination of conscience. These works were not accessible to the average person. For a discussion of these works, see Hughes, passim.

33. Mary Flowers Braswell, The Medieval Sinner: Characterization and Confession in the Literature of the English Middle Ages (London: Associated University Press, 1983), pp. 12-13. The scholar who coined the term "engin" for this meaning is Robert W. Hanning; he is paraphrased by Braswell.

34. The possibility that exposure to works of a more literary or scholarly nature on the part of certain members of the peasantry might have been considerable, at least by the sixteenth century, is discussed in Carlo Ginzburg, The Cheese and the Worms: The Cosmos of a Sixteenth-Century Miller, trans. John and Anne Tedeschi (Baltimore: Johns Hopkins University Press, 1992).

35. The questions posed of medieval sermon literature have lately increased in both number and complexity. In the introduction to a recent volume on medieval sermons, Nicole Beriou comments: "Older studies of medieval sermons usually concentrated on such topics as the history of preaching itself, the relation of preaching to technical treatises on how to do it (the artes praedicandi), the anecdotal detail about social practice which sermons incidentally reveal, mystical content (in the case of German vernacular sermons), sermons as sources for vernacular literature, and on the bio-bibliography of individual preachers. These are good questions, still worth asking. Among the questions which modern historians like to ask, about the Middle Ages among other periods but not especially about sermons, are some which nevertheless draw interesting answers from this class of evidence. Questions about systems of communication, about attitudes to marriage, death, the body, sanctity, and women, questions stimulated by literary and philosophical theory - these have been at the forefront of many historians' minds in recent decades" (Introd., Modern Questions about Medieval Sermons: Essays on Marriage, Death, History and Sancity, ed. Nicole Beriou and David L. D'Avray, Biblioteca Di "Medioevo Latino," 11 [Spoleto: Centro Italiano di Studi Sull'Alto Medioevo, 1994], ix). Although the questions are changing, the focus of scholarship is still far more on Latin than on vernacular sermons, as the contributions in Beriou and D'Avray's volume indicate.

36. Powell has traced the development of the Festial from Mirk's composition of the 1380s through a final printing by Wynkyn de Worde in 1532. She also notes that ecclesiastical records document an English preacher as using the Festial as late as 1589, although, as she comments, with unfortunate results for the preacher (Powell, pp. 92-93).

37. H. Leith Spencer, English Preaching in the Late Middle Ages (Oxford: Clarendon Press, 1993), pp. 311-26.

38. Ibid., p. 241.

39. Biller, p. 7. One work which employs exempla as an historical source, albeit to a small degree, is A. Murray, "Confession as a Historical Source in the Thirteenth Century," in The 
Writing of History in the Middle Ages, ed. R. H. C. Davis and J. M. Walace-Hadrill (Oxford: Clarendon Press, 1981), pp. 275-322.

40. This bias is described in detail in Spencer, pp. 311-26. Spencer demonstrates that sermons intended for the rural audience were considered inferior by urban audiences in early modern England, noting that "a sophisticated urban audience is unlikely to relish being addressed in a manner deemed at best suitable for yokels" (p. 241).

41. G.R. Owst, Preaching in Medieval England: An Introduction to Sermon Manuscripts of the Period c. 1350-1450 (Cambridge: Cambridge University Press, 1926), p. 22.

42. Stroup, p. 35.

43. Ibid., p. 32.

44. Owst, p. 245.

45. Hughes, pp. 92-93.

46. Haigh stresses the non-linear nature of historical developments related to the reformations (pp. 12-21 et passim). 